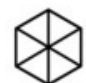 \\ LEUPHANA \\ UNIVERSITÄT LÜNEBURG
}

\section{Essay}

Braun, Susanne

Published in:

German Law Journal

DOI:

$10.1017 /$ S2071832200013298

Publication date:

2004

\section{Document Version}

Publisher's PDF, also known as Version of record

Link to publication

Citation for pulished version (APA):

Braun, S. (2004). Essay: the European private company: a supranational company form for small and mediumsized enterprises? German Law Journal, 5(11), 1393-1408. https://doi.org/10.1017/S2071832200013298

\section{General rights}

Copyright and moral rights for the publications made accessible in the public portal are retained by the authors and/or other copyright owners and it is a condition of accessing publications that users recognise and abide by the legal requirements associated with these rights.

- Users may download and print one copy of any publication from the public portal for the purpose of private study or research.

- You may not further distribute the material or use it for any profit-making activity or commercial gain

- You may freely distribute the URL identifying the publication in the public portal ?

Take down policy

If you believe that this document breaches copyright please contact us providing details, and we will remove access to the work immediately and investigate your claim. 


\title{
Essay -The European Private Company: A Supranational Company Form for Small and Medium-sized Enterprises?
}

\author{
By Susanne Braun*
}

\section{A. Introduction}

The completion of the internal market and its improvement of the economic, legal and social situation throughout the EU requires the removal of trade barriers and the adoption of production structures on the EU dimension. Especially with a view to small and medium-sized enterprises (SMEs), Member States have to reduce burdens on business start-ups as well as the time taken to register a new business or the cost of registration. The improvement and simplification of legislation and regulation has become a priority. Above all, dynamic and flexible company law is essential for a modern, dynamic, interconnected industrialized society. If the business of SMEs is not limited to satisfy purely local needs they should be able to plan and carry out the reorganization of their business on an EU scale. ${ }^{1}$ In the European Charter for Small Business, ${ }^{2}$ adopted by the General Affairs Council in Lisbon on 13 June 2000 and endorsed at the Feira European Council Meeting on 19-20 June 2000, it was noted that SMEs are the backbone of Europe's economy and the key to its competitiveness especially in the drive to make Europe the world's most competitive and dynamic knowledge-based economy. ${ }^{3}$ Their small size makes them very sensitive to changes in the commercial environment in which they operate. But until now, innovation and technology potentials have not yet been fully exploited, and inter-firm cooperation, clustering and networking experiences are still insufficiently developed because of the various legal, administrative and financial weakness still hampering further progress. So the High Level Group of Company Ex-

\footnotetext{
* Dr. iur., Law Institute of the University of Lueneburg/Germany. Susanne.Braun@uni-lueneburg.de

1 See point (1) of Council Regulation of 8 October 2001 on the Statute for a European Company (SE), 2001 O.J., (L 294) 1.

2 Report on the implementation of the European Charter for small enterprises, 13 February 2003, Com (2003) 21 final/2; Report on the implementation of the European Charter for small enterprises in the candidate countries for accession in the European Union, 21 January 2003, SEC (2003) 57, 1.

${ }^{3} I d$.
} 
perts stated that the EU company law has not kept up with developments which shape its role and application, in particular the creation of a single EU market which companies and their investors wish to use the optimum, the development of European securities markets and their regulation, the development of modern information and communication technologies which should be facilitated and could be used to improve company law arrangements and the development of corporate governance practices and standards. ${ }^{4}$

Therefore company law should concentrate on the efficiency and the competitiveness of business. ${ }^{5}$ In pursuit of the modernization of European company law and the harmonization of national company law, the efforts of the European lawmakers have been and are still characterized by two initiatives: establishing new, tailored company forms completing the EU framework; and adopting European Directives harmonizing the different national company laws. If harmonization measures are implemented by Directive, each Member State would have to enact national legislation. The subject of the measure would finally be a product of a national legal order and often it is nearly impossible to give it a "European" - supranational - character. Apart from rare exceptions the important work of harmonizing company law only concerned public limited companies. ${ }^{6}$ In 2003, the European Commission noted that "the time is right to give a fresh and ambitious impetus to the EU company law harmonizing process", 7 whereas actually the great dynamic of legal harmonization seems to be over with the increasing number of Member States in the EU. But further actions are needed to simplify the legal and economic framework in which companies operate within the EU.

Referring to supranational company forms the existing European Economic Interest Group (EEIG), ${ }^{8}$ the European Company $(\mathrm{SE})^{9}$ or the European Cooperative Society

\footnotetext{
${ }^{4}$ Report of the High Level Group of Company Law Experts on a modern regulatory framework for company law in Europe, 4 November 2002, 1, available at http://europa.eu.int/comm/internal_market /en/company/company/modern/consult/report_de.pdf

${ }^{5}$ Id. at 27 .

${ }^{6}$ Boucourechliev, European Perspectives: Initiatives in Favour of a European Law Company, 1 (1999) at http://www.creda.ccifr/colloque/13spe/13-04aspdf

7 Communication from the Commission to the Council and the European Parliament: Modernising Company Law and Enhancing Corporate Governance in the European Union - A plan to move forward, 21 May 2003, COM (2003) 284, 6, at http://europa.eu.int/eur-lex/eng/com/cnc/2003/com2003_0284 de01.pdf

${ }^{8}$ Council Regulation No 2137/85 of 25 July 1985 on the European Economic Interest Group, 1985 O.J. (L 199) 1.
} 
$(\mathrm{SCE})^{10}$ do not provide an adequate company form for SMEs. The EEIG is a legal instrument for promoting the cooperation between European enterprises without making profits for itself. Its activities must be the continuation of its members' activities and cannot replace them. The SE represented a major breakthrough allowing European companies to merge across borders and to transfer their seat from one Member State to another. ${ }^{11}$ But the Statute often refers to the law of the Member State of incorporation so that, as a result, different types of SE may come to exist depending on where they have been incorporated. Furthermore the SE seems to be designed for large enterprises because of the minimum capital requirement 120,000 $€$ and the different forms of creation. It may not meet all the expectations of the business community. SMEs often serve niche markets because of their high degree of specialization. The setting up of subsidiaries abroad is complex and costly. They need legal advice with respect to the requirements for setting up a company and to other local company law provisions, dealing in the worst case with 25 different company law systems within the EU. In order to prevent competitive disadvantages for SMEs, when compared with larger enterprises, SMEs must obtain the possibility to organize their European-wide business activities by using a Europeanwide type of company. ${ }^{12}$ An European Private Company (EPC) as a further supranational legal company form could be the solution, if its statute corresponds to the special requirements of the SMEs.

In the following, after defining SMEs, the special requirements of the SMEs to a company form will be elaborated before presenting and discussing the proposed EPC Statute. Finally I will place this proposal against the background of the otherwise continuing discussion of the Action plan of the European Commission. ${ }^{13}$

\footnotetext{
${ }^{9}$ Council Regulation No 2157/2001 of 8 October 2001 on the Statute for a European Company, 2001 O.J. (L 294) 1, Council Directive 2001/86/EC of 8 October 2001 Supplementing the Statute for a European Company with Regard to the Involvement of Employees, 2001 O.J. (L 294) 22.

${ }^{10}$ Council Regulation No 1435/2003 of 22 July 2003 on the Statute for a European Cooperative Society, 2003 O.J. (L 207), 1, Directive 2003/72/EC of 22 July 2003 supplementing the Statute for a European Cooperative Society with regard to the involvement of employees, 2003 O.J. (L 207) 1.

${ }^{11}$ For an account of the legislative history and the final scope of the SE, see Teichmann, 4 GERMAN L. J. No. 4, 309 (1 April 2003) at http://www.germanlawjournal.com/article.php?id=259.

12 Orgalime, Creation of a European Private Company - Position Paper, 24 October 2002, available at http://www.orgalime.org/positions/epc.htm; HELMS, DIE EUROPÄISCHE PRIVATRECHTSGESELLSCHAFT 11 (1998).

${ }_{13}$ Communication from the Commission to the Council and the European Parliament: Modernising Company Law and Enhancing Corporate Governance in the European Union - A plan to move forward, 21 May 2003, COM (2003) 284, 21, at http://europa.eu.int/eur-lex/eng/com/cnc/2003/com2003_0284 de01.pdf
} 


\section{B. Definition of SME}

The question whether there is a need to create a new supranational company form for SMEs can only be answered on the base of a uniform "European" definition of SMEs. Some Member States had no general definition and for a long time operated with ad hoc rules based either on local practice or applied only to particular sectors. Others adhered rigidly to the definition contained in the Community guidelines on State aid to SMEs. ${ }^{14}$ But the existence of different definitions at Community level and at national level can create inconsistencies and can also distort competition between enterprises.

In 1996 the European Commission issued a Recommendation concerning the definition of small and medium-sized enterprises. According to this Recommendation, ${ }^{15}$ medium-sized enterprises are understood to have fewer than 250 employees. Furthermore, their annual turnover should not exceed 40 million ECU or their annual balance-sheet total should be less than 27 million ECU. Small enterprises have between 10 and 49 employees and they should have an annual turnover not exceeding 7 million ECU or an annual balance-sheet total not exceeding 5 million ECU. Micro-enterprises are enterprises, which have fewer than 10 employees.

While the European Commission invites the Member States, the European Investment Bank and the European Investment Fund to apply a common definition of small and medium-sized enterprises, the Member States, the European Investment Bank and the European Investment Fund are not obliged to adopt these definitions. Adoption of these definitions is compulsory when it comes to State aid allowing SMEs to benefit from preferential treatment over other enterprises, when such treatment is authorized by Community regulation.

Each enterprise must be independent, - i.e. $25 \%$ of the capital or the voting rights may not be owned by one enterprise, or jointly by several enterprises, falling outside the definition of an SME or a small enterprise. This threshold may be exceeded in the following two cases: if the enterprise is held by public investment corporations, venture capital companies or institutional investors, provided no control is exercised over the enterprise or if the capital is spread in such a way that an enter-

\footnotetext{
${ }^{14}$ Community guidelines on State aid to SMEs, 1992 O.J. (C 213) 2.

${ }^{15}$ Commission Recommendation of 3 April 1996 concerning the definition of micro, small and mediumsized enterprises (1996/280/EC), 1996 O.J. (L 107) 4: as of 1 January 2005 this Recommendation will be replaced by Commission Recommendation of 6 May 2003 concerning the definition of micro, small and medium-sized enterprises (2003/361/EC), 2003 O.J. (L 124) 36 and the Ecu will be replaced by Euro.
} 
prise can legitimately declare that it is not owned, in excess of $25 \%$, by one or more enterprises falling outside the definitions of an SME.

\section{Requirements of SMEs' to an EPC}

In the next step, it is necessary to determine the requirements of the SMEs so as to find the type of company seeking Europe-wide facilitation as an SME. In fact, the relevant entities exist with a range of internal characteristics of a company type, including capital, actual management structures and general function. These characteristics can qualify as important orientation points for a definition of the requirements of SMEs to become recognized as a supranational company form.

An EPC as a new supranational company form should be based on contractual freedom in order to facilitate a flexible and always up-to-date structure of a company, ${ }^{16}$ taking into account the impact of modern technology, - i.e. concerning the form of legal acts and of shares or the disclosure and filing requirements of company information. The scope should not be limited and encroached upon by mandatory or default provisions of national laws. The contractual freedom should cover the determination of the corporate governing bodies, the organization of relations among them or the shareholders' rights. ${ }^{17}$ In contrast, mandatory laws are necessary to ensure the essential rights of shareholders and third parties.

It must be possible to set up the EPC in the country of choice and to transfer it to another country without any impediments. This means a Statute should foresee cross-border mergers and better transparency in mergers. According to the recommendations of the High Level Group of Company Experts, the EPC should be adaptable to each undertaking, facilitating SMEs' business. The company form has to be suited to SMEs wishing to find a simple way to establish subsidiaries. It should be open to individuals and not only for companies. The founders should not be required to come from several Member States in order to allow a full development of this form of company within the European Union. A requirement of undertaking economic activities in at least two Member States would be sufficient to justify an European legal form for SMEs instead of the requirement that companies from at least two Member States are to be involved in the incorporation of an EPC, which would not be suited for SMEs.

\footnotetext{
${ }^{16}$ Drury \& Hicks, The Proposal for a European Private Company, in THE JOURNAL OF BUSINESS LAW 436 (1999): In France and in Germany internal company law developments aimed at increasing flexibility by introducing a new and supple form or by making existing forms less rigid, ex. "Société par actions simplifiées" in France, "Kleine Aktiengesellschaft" in Germany.

${ }^{17}$ Boucourechliev, supra note 6 , at 3 .
} 
Despite the priority given to contractual freedom, the protection of the members and third parties should be secured. ${ }^{18}$ The legal costs for setting up subsidiaries, including the drafting of company statutes, should be reduced and the minimum capital should be not too high. A possible and realistic solution would be to apply Article 6 of the Second Company Law Directive, ${ }^{19}$ which sets the limit at 25,000 $€$ as share capital. Finally, there is a wish for a genuine European company, which is not subject to national laws, securing the unitary and Europe-wide character, versatile to the SE. ${ }^{20}$ The European label may be useful for SMEs on the commercial market if the company does its business as an European SME and not as a national one. To be recognized as a real supranational company questions of interpretation have to be solved by the European Court of Justice and not by national courts. ${ }^{21}$ A Statute providing cross-references to national company law must be avoided. A mixture between European and national provisions would create more rather than less need for information and legal advice and finally costs.

\section{The proposal of the EPC Statute}

I shall briefly sketch the history leading to the proposal, before I provide an overview of the provisions with the focus on a few main points such as: general conception, incorporation methods, capital including capital increase and reduction, name, governing law, and finally, the organization of the company and employees' rights.

\section{History of the EPC Statute}

In 1959 the original proposal for a European Company, emerged from the Council of Europe, which failed to produce an agreed text, was presented at the $57^{\text {th }}$ Congress of French Notaries.22 A draft regulation was published by the European Commission in 1970.23 In 1995 CREDA, the research department of the Paris Chamber of Commerce and Industry, set up an international project to investigate the

\footnotetext{
${ }^{18}$ Report of the High Level Group of Company Law Experts on a modern regulatory framework for company law in Europe, 13 (2002) available at http://europa.eu.int/comm/internal_market/ en/company/company/modern / consult/report_de.pdf

${ }^{19}$ Second Company Law Directive 77/91/EEC, 1977 O.J. (L 26) 1.

${ }^{20}$ See Art. 9 of the Council Regulation on the Statute for a European company; Kübler, Leitungsstrukturen der Aktiengesellschaft und die Umsetzung des SE-Statuts, in: ZHR 222, 224 (2003) speaks of nine levels.

${ }^{21}$ Drury \& Hicks, supra note 16.

${ }^{22} I d$.

${ }^{23} I d$.
} 
prospects for an European private company. ${ }^{24}$ Researchers from Germany, the Netherlands, the United Kingdom and France approached the issue from their own national perspectives and put forward their conclusions in a book published by the European Commission in 1997.25 This private initiative has resulted in a specific and detailed proposal for a European Private Company (EPC). This company form would be complementary to the national forms of private companies in Member States and to the SE. In September 1998, the proposal was presented by the Paris Chamber of Commerce and Industry, the French business organization MEDEF. It was drafted by a group of company representatives and specialists in company law from several nationalities and has been supported by the Union of Industrial and Employers' Confederation of Europe (UNICE) and EUROCHAMBERS. In March 2002 the European Economic and Social Committee adopted an opinion on an European Company Statute for SMEs stressing the necessity of this project for SMEs. ${ }^{26}$

\section{General Conception}

The EPC is a company form with legal personality from the time of its registration. According to Article 2 no securities or bearer shares are issued. It is impossible to issue shares accessible to the public. This form of a "closed company" 27 could be an instrument to limit the size of the company in order to avoid the application of codetermination rules and to get more experienced partners involved in the company than would probably be the case in a public company where shareholders are often merely placing an investment in a prospering firm with little or no specific interests in the concrete doings of the operation.

Another basic principle of the EPC is the limitation of the shareholders' liability. The shareholder shall be liable only to the extent of the contribution made. Because of the devices of limited liability and corporate personality, the EPC trades with a finite body of assets posing a certain risk to a third party. The form of a "closed company" makes it impossible to issue shares to the public. If the assets are gone, there the company is insolvent and creditors may not be satisfied in full.

\footnotetext{
${ }^{24} I d$.

${ }^{25}$ Propositions Pour Une Societe Fermee Europeenne (Boucourechliev ed., 1997).

${ }^{26}$ European Commission, A modern regulatory framework for company law in Europe - A consultative document of the High Level Group of Company Law Experts, available at http://europa.eu.int/comm/ internal_market/en/company/company/modern/consult/1_en.htm

27 HELMS, supra note 12, at 105; Drury/Hicks, supra note 16.
} 


\section{Incorporation}

According to Article 1, the EPC may be incorporated by one or a group of individuals or legal entities, regardless of whether these are nationals of a Member State, in the conditions and in the manner provided for under this Statute. On the one side, the EPC is created by transactions such as cross-border mergers, establishment in several Member States or by the creation by shareholders from different Member States. On the other side the creation of a single-person EPC may be possible. The incorporation methods, derived from Article 1, are described in Article 5. The procedure for transformation into this new European form of company needed to be defined. So an EPC may be incorporated by means of creation or transformation, whether or not connected with a merger or division. It relies extensively on the transposed provisions of the First European Directive on co-ordination of safeguards, which for the protection of the interests of members and others, are required by Member States of companies within the meaning of the second paragraph of Article 58 of the Treaty, with a view to making such safeguards equivalent throughout the Community ${ }^{28}$ and the Third European Directive concerning mergers of public limited liability companies. ${ }^{29}$

So, there is an unrestricted access to this company form, which is useful even if the Member States were to select the former approach.

\section{Capital}

According to Article 3, the capital of the EPC shall be divided into shares of a fixed amount. It shall not be less than $25,000 €$ or an equivalent amount, at the time of registration, in another currency. Despite all contractual freedom, a statutory minimum capital is required in order to prevent unjustified or reckless creations. ${ }^{30}$ The amount corresponds in fact to the amount fixed in Article 6 of the Second Directive for public limited companies.

The capital shall be subscribed for and paid in full at the time of registration. The share capital may be contributed in cash or in kind, but not in work or services. The funds generated by payment for the shares shall be deposited for this account of the company being incorporated by the parties who have received them, within eight days after receipt thereof, with a notary or a bank, in exchange for an acknowl-

\footnotetext{
${ }^{28}$ First Directive 68/151/EEC, 1968 O.J. (L 65) 8.

${ }^{29}$ Third Directive 78/855/EEC, 1977 O.J. (L 295) 36.

${ }^{30}$ HeLMS, supra note 12, at 126-127; Drury/Hicks, supra note 16, at 441: But the provisions of a minimum capital has not always the effect of providing any sort of guarantee that the business is sufficiently capitalised to protect third parties dealing with it.
} 
edgement of receipt. The articles of association shall contain a valuation of each contribution in kind. According to Article 4, the valuation shall be performed on the basis of a report appended to the articles of association and drafted subject to his, her or its own responsibility by an expert authorized to perform the statutory review of accounts.

The provisions concerning capital (Article 3), valuation of contributions in kind (Article 4) and capital increase and reduction (Article 26) secure the reality and maintenance of the capital and the transparency of changes in its amount, being in line with the Second Directive. ${ }^{31}$

\section{Name}

Pursuant to Article 7, the EPC shall select a corporate name which may include the object of the company, the name of one or more shareholders, or being entirely imaginary, provided that it must be not misleading or liable to cause confusion. The company's name shall be preceded or followed immediately by the words "European Private Company" or the acronym "EPC".

\section{Governing Law ${ }^{32}$}

Principally, the regulation itself is binding. Article 12 sets out the structure of sources of law for the regulation's application. Thus, the EPC shall be governed by the provisions of this regulation and the provisions of the EPC's articles of association, provided that they are not inconsistent with it. With regard to the diversity of national law, the provisions of the regulation and those of the articles of association are shielded from the application of the Member States' laws. Only the general principles of the regulation or European company law and those common to the national rules may be asserted to assist in construction of the provisions in the regulation and articles. The provisions of national company law apply only in case of an express reference. Apart from company law the EPC is subject to the generally applicable rules of the Member State where its seat is located whether as regards employment, accountancy, tax legislation, procedures for insolvency and cessation of payments and criminal law.

\footnotetext{
${ }^{31}$ Second Company Law Directive 77/91/EEC, 1977 O.J. (L 26) 1.

32 Drury \& Hicks, supra note 16, at 448: This was one of the most difficult and pressing problems connected with the project.
} 


\section{Organization of the company}

The Statute, at Article 14, establishes a duty for the shareholders to define the company's organization and operation in the articles of association. Despite the basic principle of contractual freedom such a definition is necessary in order to avoid indecision and differences in interpretation. ${ }^{33}$ The scope for freedom of agreement has to be positively determined, because certain options available under the regulation are unknown (i.e. in Germany the board or one tier system) or even banned under certain national laws, or there is an emerging risk of restrictive construction of the regulation's silence which has to be avoided. The Statute neither fixes one organizational model nor imposes alternatives as the Societas Europaea (SE) Statute.

Pursuant to Article 16, the EPC shall be represented in relation to third parties by one or more individuals or legal entities having full powers to act in all circumstances in the company's name.

\section{Employees' Rights}

According to Article 33 the rules relating to disclosure to and consultation with employees and, if applicable their involvement in the corporate bodies, shall be determined by the law applicable to the registered office of the EPC.

As for the SE, -the rules on the involvement of employees in the SE are laid down in a separate directive. Those provisions form a complement to the regulation on the Statute and must be applied concomitantly.- The Statute of the EPC has no detailed provision concerning the rights of employees.

\section{E. Creation of national companies after Inspire Art}

It remains to be seen if, with the decision Inspire Art 34 by the European Court of Justice of 30 September 2003, there is still a need for the supranational EPC or whether entrepreneurs will now prefer creating a company according to the national law of one Member State, regardless of their envisioned prime place of conducting business. Before this decision, the consequences of a transfer of the admin-

\footnotetext{
${ }^{33}$ HeLMS, supra note 12 , at 142.

34 ECJ Case C-167/01, 48 AG 680 (2003); English version available at http://europa.eu.int/eurlex/en/index.html; see the comments by ERICH SCHANZE \& ANDREAS JÜTTNER, DIE AKTIENGESELLSCHAFT 661 (2003); Silja Maul, 58 BetriebsBerATER 2297 (2003); Christian Kersting \& Clemens Philipp Schneider, , 4 GERMAN L.J. 1277 (1 December 2003), at http:/ / www.germanlawjournal.com/article.php?id=344
} 
istrative seat of a company, created in one Member State concerning its respect as a legal entity of the host Member State remained a crucial impediment to an effective transfer of seat. In the absence of a single and clear regulation, two approaches eventually developed: the place-of-incorporation approach ${ }^{35}$ and the so-called real seat (siège réel) approach. ${ }^{36}$ The real seat approach regards the law of that state to be applicable where the actual centre of administration of the company is located. Following this approach a company's existence as a legal entity in one Member State will not be respected by another Member State after the transfer of the seat. ${ }^{37}$ The place-of-incorporation approach determines the applicable law according to the statutory seat of a company. According to this approach the transfer of the seat did not have any consequences for the respect as a legal entity. ${ }^{38}$ Despite many efforts these two approaches were regarded as unbridgeable opposites and no effective compromise could be found. ${ }^{39}$

Beginning in 1999 and culminating in the Court's Inspire Art decision, the European Court of Justice clarified that a foreign company is not only to be respected as a legal entity having the right to be a party to legal proceedings but rather has to be respected as such, as a foreign company that is subject to the company law of the host state of incorporation. ${ }^{40}$ Pursuant to Article 43 and the following provisions of the Treaty establishing the European Community, any adjustment to the company law of the host state is not compatible with the European law, guaranteeing the freedom of establishment. Questions concerning the freedom of establishment of companies have always been a central and controversial area of Community law. In its Daily Mail decision ${ }^{41}$ of 1988 the Court held that the right of establishment does not include the right of a company incorporated under the legislation of a Member State to transfer its central management and control to another Member State. This

\footnotetext{
35 The Anglo-American countries followed this approach. See Lüdertz, in SOERGEL, KOMMENTAR ZUM BGB, (12th ed. 1992), Art. 10, annotations 9, 13.

${ }^{36}$ This approach was respected in Germany, Belgium, France, Luxemburg, Spain, Portugal, Greece. See Id. at Art. 10, annotation 4.

37 KindleR IN MÜNCHENER KOMMENTAR, INTERNATIONALES GESELlSCHAFTSRECHT para. 312 (1999); GROßFELD IN STAUDINGER, INTERNATIONALES GESELLSCHAFTSRECHT para 20, 26 (1998).

${ }^{38}$ KINDLER, supra note 37, at para. 256; Großfeld GROßFELD, supra note 37, at para. 20, 22.

${ }^{39}$ Behrens, Die grenzüberschreitende Sitzverlegung von Gesellschaften in der EWG, 9 IPRax 354 (1989); Knobbe-Keuk, Umzug von Gesellschaften in Europa, 154 ZHR 325 (1990); Ulmer, Schutzinstrumente gegen die Gefahren aus der Geschäftstätigkeit inländischer Zweigniederlassungen von Kapitalgesellschaften mit fiktiven Auslandsitz, 54 JZ 662 (1999).

${ }^{40}$ Case C-167/01, Inspire Art, in: 48 AG 680, 683 (2003).

41 Case C-81/87, Daily Mail, 1988 E.C.R. I - 5483.
} 
decision was widely (but wrongly) considered as a confirmation of the real seat approach.42 In 1999 with the Centros decision ${ }^{43}$ the Court apparently "changed" its opinion. ${ }^{44}$ Still, many Member States held on the real seat doctrine because this case concerned only a branch of a company incorporated in the law of another Member State. With the Überseering decision ${ }^{45}$ in 2002 the European Court of Justice gave a wide interpretation to the right of establishment. The companies can now move their central management and control from one Member State without the need for further proceedings. ${ }^{46}$ A company can now be incorporated in a Member State without having its primary business in that state. Whereas Daily Mail and Überseering were cases of the primary freedom of establishment, Inspire Art and Centros relate to the secondary freedom of establishment. In contrast to the facts in Centros, Inspire Art was concerned not with the registration of a branch, but with the admissibility of a special regime dealing with pseudo-foreign companies.

All these decisions concerned the legal capacity of a company, without, however, containing a clear and comprehensive treatment, let alone answer, to the long disputed validity of the real seat theory. With Inspire Art, however, the Court effectively rejected the real seat approach when it held the requirements of the Dutch authorities (based on its real seat doctrine) to be in violation of the right of establishment. ${ }^{47}$ Even if a company had been set up in one Member State with the sole aim of establishing itself in another Member State, - a so-called pseudo-foreign

42 See for a comprehensive discussion, HALBHUBER, LIMITED COMPANY STATT GMBH? (2001); see National Doctrinal Structures and European Company Law, 38 COMMON MKT. L. REV. 1385 (2001); see also Ebke, Centros - Some Realities and Some Mysteries, 48 AM. J. COM L. 623 (2000).

${ }^{43}$ Case C-212/97, Centros, 1999 E.C.R. I - 1459.

${ }^{44}$ See Halbhuber and Ebke, supra, note 42.

${ }^{45}$ Case C-208/00, Überseering, 2000 E.C.R. I - 9919. See, e.g., the comments by Bälz \& Baldwin, The End of the Real Seat Theory (Sitztheorie): the European Court of Justice Decision in Überseering of 5 November 2002 and its impact on German and European Company Law, 3 GERMAN L.J. No 12 (2003) at http://www.germanlawjournal.com/current_issue.phd?id=214; Mock, Harmonization, Regulation and Legislative Competition in European Corporate Law, 3 GERMAN L.J. No 12 (2003) at http:/ / www.germanlawjournal.com/current_issue.php?id=216; Behrens, Das Internationale Gesellschaftsrecht nach dem Überseering-Urteil des EuGH und den Schlussanträgen zu Inspire Art, 193 IPRax (2003); Wymeersch, The Transfer of the Company's Seat in European Company Law, ECGI LAW WORKING PAPER N. 08/2003 and CMLR 2003 (40), 661.

46 See Bälz \& Baldwin, supra note 45; see also Wooldridge, Überseering: Freedom of Establishment of Companies Affirmed, 14 EUROPEAN BUSINESS LAW REVIEW [EBLR] 227 (2003); Roth, From Centros to Ueberseering: Free Movement of Companies, Private International Law, and Community Law, 52 INT'L \& COMP. L.Q. 177 (2003).

${ }^{47}$ Questions concerning the freedom of establishment of companies have always been both a central and controversial area of Community law. 
company, where its main or entire business was to be conducted, a restriction of the freedom of establishment is not allowed, except - as had been the loophole established in Centros - in cases of fraud. ${ }^{48}$ The Court also held that a provision requiring pseudo-foreign companies to have a capital at least equivalent to the minimum capital prescribed for companies according to the national law constituted a violation of the freedom of establishment. If a company presented itself clearly enough as a foreign and not a national company, the creditors - so the ECJ - would be sufficiently informed about the circumstances and there would be no room for an application of the host state rules on legal capital etc. ${ }^{49}$ The interests of creditors, minority shareholders, employees, and the treasury can - under certain circumstances and within special prerequisites - justify restrictions of the freedom of establishment if these restrictions are qualified as imperative requirements in the public interest. 50

Following the landmark decisions of the European Court of Justice, the place-ofincorporation approach will lead to an increased elevation of certain principles to the status of public policy, especially in the Member States, who followed the real seat approach. The state of incorporation as the creator of the company is at liberty to prohibit the transfer of the head office and/or the statutory seat to another state. ${ }^{51}$ If the state of incorporation allows the transfer, the host state is obliged to acknowledge the foreign company as such. ${ }^{52}$

Since these decisions by the European Court of Justice, it has been argued by many scholars that an entrepreneur searching for an adequate company form might now prefer to create a Ltd. in the United Kingdom without any minimum capital instead of choosing the company form of EPC with the capital requirement of 25,000 $€$ and without the risk of not being acknowledged as legal entity by other Member States. ${ }^{53}$ If English company law does not require a Ltd. to subscribe and maintain a

\footnotetext{
${ }^{48}$ See Kersting \& Schindler, The ECJ's Inspire Art Decision of 30 September 2003 and its Effects on Practice, 4 GERMAN L.J. No 12, 1277 (2003) at http://www.germanlawjournal.com/pdf/Vol04No12/ PDF_Vol_04_No_12_1277-1291_Privat_Kersting_Schindler.pdf

${ }^{49}$ Schanze \& Jüttner, Kollisionsrecht und Gesellschaftsrecht nach „Inspire Art“, 48 AG 661, 663 (2003).

${ }^{50} I d$.

${ }^{51}$ Case C-167/01, 48AG 680 (2003).

52 See Inspire Art, supra note 40.

53 See Bayer, Die EuGH-Entscheidung "Inspire Art" und die deutsche GmbH im Wettbewerb der europäischen Rechtsordnungen, 58 BB 2357 (2003); Ziemons, Freie Bahn für den Umzug der Gesellschaften nach Inspire Art?, 42 ZIP 1913 (2003); Wachter, Errichtung, Publizität, Haftung und Insolvenz ausländischer Kapitalgesellschaften nach Inspire Art, GmbHR 1254 (2003): arguing to the contrary.
} 
minimum base of capital, a Ltd. cannot per se be considered undercapitalised. ${ }^{54}$ This, however, only focuses on the capital aspect.

Furthermore, it is possible that some Member States do not totally accept the placeof-incorporation approach for pseudo-foreign companies but prefer a modified or restricted place-of incorporation approach. ${ }^{55}$ It is also possible for the host states to introduce some special connexions for the protection of public interest in order to apply national law despite the transfer of the seat. ${ }^{56}$

Regardless (one might say), the free choice of company law does by no means provide a full guarantee of entrepreneurial success. Intensive knowledge of the chosen "foreign" company law (of the host state) is necessary. The advantages (e.g., no minimum capital requirements) of another legal system must carefully be weighed against the needs (and costs) for consultation private (contract/tort) law, company law or tax law. So, while Inspire Art surely increases the choices for the entrepreneur the remaining problems suggest that at least the recent ECJ case law has not as such rendered the EPC unnecessary. One should, after all, not underestimate the European "label" that accompanies this supranational company.

\section{F. Conclusion}

Despite the principle possibility of creating partnerships, of initiating mergers or (hostile) takeover bids, the EPC as a supranational company form would be of considerable use in complementing SMEs in their limited capacity to perform on globally integrated markets. Likewise, an EPC as a supranational company form could meet more of the requirements confronting enterprises in the EU and beyond. ${ }^{57}$

If, however, the specific needs of SMEs could also be met in a satisfactory fashion by way of modernizing national rules for existing private companies, this would indeed underscore claims that the EPC contributes more clutter to the European corporate environment with just another legal form for which there is no specific need. But this argument, too, has been rejected by the Action Plan "Modernising Company Law and Enhancing Corporate Governance in the EU" that was pre-

\footnotetext{
54 Großerichter, Ausländische Kapitalgesellschaften im deutschen Rechtsraum: Das deutsche Internationale Gesellschaftsrecht und seine Perspektiven nach der Entscheidung "Überseering“,169 DStR 159 (2003).

55 Diego, Gemeinschaftsrechtskonformität mitgliedstaatlicher Reglementierungen des Wettbewerbs der Gesellschaftsrechtsordnungen in der EG, 6 JURA 400, 401 (2004).

${ }^{56}$ Forsthoff, Internationales Gesellschaftsrecht im Umbruch, DB 979, 981 (2003).

57 Boucourecheliev, supra note 6.
} 
sented by the European Commission in May 2003. The main aims of the plan are to strengthen shareholders rights, to reinforce protection for employees and creditors and to increase the ecciciency and competitiveness of business. ${ }^{58}$ As regards the creation of new European legal company forms, the Commission intends to actively support ongoing legislative processes such as those on a statute for a European Association and a European Mutual Society. ${ }^{59}$ Furthermore, the development of a proposal for a Regulation on a European Foundation would be possible. Concerning the EPC, the Action Plan refers to the statement of the High Level Group. ${ }^{60}$ The Group noted that the EPC, as a new legal form at the EU level, would primarily serve the needs of SMEs which are active in more than one Member State

And yet, the first priority should be to pursue the adoption of the Tenth Directive on cross border mergers ${ }^{61}$ which is expected to meet one of the purposes for which the creation of the EPC is advocated. The Directive will give a suitable legal instrument to all companies and enable them to carry out cross-border mergers under the most favourable conditions. But the scope of the Directive will be drawn in such a way as to cover, above all, SMEs which stand to benefit because of their smaller size and lower capitalization compared with large enterprises which, for the same reasons, the SE Statute does not provide a satisfactory solution. ${ }^{62}$ With a view to this Directive proposal, the Group recommended that the Commission should launch a feasibility study in order to clearly identify the practical benefits of and problems related to the introduction of an EPC statute before deciding on the submission of a formal proposal. In consequence, the Commission will launch such a study in the short term (2003- 2005) with a view to presenting a proposal for an EPC statute (if the feasibility study confirms the need for such an initiative) in the medium term $(2006-2008) \cdot{ }^{63}$

\footnotetext{
${ }^{58}$ Communication from the Commission to the Council and the European Parliament: Modernising Company Law and Enhancing Corporate Governance in the European Union - A plan to move forward, 21.05.2003, COM (2003) 284, 8, 9, available at http://europa.eu.int/eurlex/eng/com/cnc/2003/com2003_0284de01.pdf

${ }^{59}$ Nagel, Wirtschaftsrecht der Europäischen Union, 4. Auflage 338 (2003).

${ }^{60}$ Report of the High Level Group of Company Law Experts on a modern regulatory framework for company law in Europe, 2002, 113, available at

http://europa.eu.int/comm/internal_market/en/company/company/modern/consult/report_de.pdf

${ }^{61}$ Proposal for a Directive of the European Parliament and of the Council on cross-border mergers of companies with share capital, 18.11.2003, Com (2003) 703 final.

${ }^{62} I d$.

${ }^{63}$ Communication from the Commission to the Council and the European Parliament: Modernising Company Law and Enhancing Corporate Governance in the European Union - A plan to move forward,
} 
This feasibility study is very important, ${ }^{64}$ especially with respect to the recent jurisprudence of the European Court of Justice and its effects on practice. In any event, after Inspire Art only the access to foreign markets is facilitated without any prejudice, naturally, on the business success of the operation in the European market. As already mentioned, the confrontation with another company law system is usually accompanied by an extensive recourse to legal advice and a need for information. Furthermore a subsidiary in a Member State lacks the label of a supranational company form, an aspect that can be of high relevance for competitive advantages. Thus, the need for an EPC still seems to exist. ${ }^{65}$ The EPC as a real supranational company would be a contribution to more transparency with respect to risks such as company and management liability and thus constitute important progress towards more deregulation. ${ }^{66}$ The feasibility study is just the first step.

21.05.2003, COM (2003) 284, 21, available at http://europa.eu.int/eur-lex/eng/com/cnc/2003/com 2003_0284de01.pdf

${ }^{64}$ Van Hulle \& Maul, Aktionsplan zur Modernisierung des Gesellschaftsrechts und Stärkung der Corporate Governance, 33 ZGR 484, 501 (2004).

${ }^{65}$ Drury \& Hicks, supra note 16, at 451: “... the European Private Company could become the corporate vehicle of first resort and a familiar feature of our common company laws in the next century."

${ }^{66} \mathrm{Id}$. at 448-449: One aim of the EPC proposal was to keep it as simple as possible, not to go in for overregulation and to end up with an enormous statute. 